\section{Australian Journal of \\ Crop Science}

AJCS 13(11):1873-1882 (2019)

doi: 10.21475/ajcs.19.13.11.p2095

\title{
Estimation of productivity gain by irrigated and fertilized forage palm plants (Opuntia ficus- indica (L.) Mill. and Nopalea cochenillifera (L.) Salm-Dyck): systematic review and meta-analysis
}

\author{
Rener Luciano de Souza Ferraz ${ }^{1 *}$, Patrícia da Silva Costa ${ }^{2}$, José Dantas Neto ${ }^{2,7}$, Pedro Roberto Almeida \\ Viégas $^{3}$, Alberto Soares de Melo ${ }^{4,8}$, Flávio da Silva Costa ${ }^{5}$, Aldair de Souza Medeiros ${ }^{6}$, Ivomberg Dourado \\ Magalhães ${ }^{6}$, Antônio Suassuna de Lima ${ }^{2}$, Constantino Antônio Cavalcante Júnior ${ }^{2}$, Vera Lúcia Antunes de \\ $\operatorname{Lima}^{2,9}$
}

\author{
${ }^{1}$ State University of Paraíba, Center for Agrarian and Environmental Sciences, Lagoa Seca, 58117-000, Paraíba, Brazil \\ ${ }^{2}$ Federal University of Campina Grande, Academic Unit of Agricultural Engineering, Campina Grande, 58109-970, \\ Paraíba, Brazil \\ ${ }^{3}$ Federal University of Sergipe, Department of Agronomic Engineering, São Cristóvão, 49100-000, Sergipe, Brazil \\ ${ }^{4}$ State University of Paraíba, Coordination of the Post-Graduate Program in Agricultural Sciences, Campina Grande, \\ 58429-570, Paraíba, Brazil \\ ${ }^{5}$ Federal University of Amapá, Field Education Coordination, Mazagão, 68940-000, Amapá, Brazil \\ ${ }^{6}$ Federal University of Alagoas, Department of Plant Production, Maceió, 57072-900, Alagoas, Brazil \\ ${ }^{7}$ Fellow of CNPq Research Productivity, level 1C, Brazil \\ ${ }^{8}$ Fellow of CNPq Research Productivity, level 2, Brazil \\ ${ }^{9}$ Fellow of CNPq Research Productivity, level 1D, Brazil
}

*Corresponding author: ferragroestat@gmail.com

\section{Abstract}

Population expansion increases the water use for food production, which has stimulated farmers to cultivate vegetable with improved water use efficiency. The purpose of this meta-analysis study was to estimate the productivity gain of irrigated and fertilized forage palm plants (Opuntia ficus-indica (L.) Mill. and Nopalea cochenillifera (L.) Salm-Dyck) compared to non-irrigated ones. A systematic review was done and productivity average, tendency and dispersion measures were carried out from a search carried out between October 23 and 27, 2017, without any restriction of date and location and use of filters. Data were submitted to normality, hierarchical grouping, and meta-analysis tests. It has been observed that irrigated forage palm plant presents an increasing production of $53.54 \mathrm{t} \mathrm{ha}^{-1}$ year $^{-1}$ when compared to non-irrigated and $80.25 \mathrm{t} \mathrm{ha}^{-1}$ year $^{-1}$, with higher irrigation levels, and $26.83 \mathrm{t} \mathrm{ha}^{-1}$ year $^{-1}$ with smaller water levels, with the possibility of even higher yields, especially in semiarid regions.

Keywords: Cactaceae; Opuntia; Nopalea; non-irrigated land; water requirement; irrigation.

Abbreviations: $A D_{-}$average of the differences; $\mathrm{CO}_{2}$ carbon dioxide; $\mathrm{D}_{-}$difference of productivity; $\mathrm{DB}$ _data base; ETo_reference evapotranspiration; $\mathrm{H}^{2}$ _relationship between the size of the confidence interval and the estimate of the measure of effect; ha hectare; $\mathrm{I}^{2}$ heterogeneity percentage variance among studies; K_number of combined studies; kg_kilogram; km_kilometer; KS_Kolmogorov-Smirnov's; LL_lower limit; MD_average of differences; mm_millimeter; N_nitrogen; $P$ _statistical significance probability; S_subgroups; SS_search strings; S-I_first subgroup; S-II_second subgroup; S-III_third subgroup; S-IV_forth subgroup; SV_fifth subgroup; t_tonne; T-E_all inputs; UL_higher limit; W_Shapiro-Wilk's statistical test; Z_hypothesis test; \%_percentage; \pm . more or less; $\tau^{2}$ estimation of variability among studies.

Introduction

Population growth, in line with the improvement of the standard of living, observed on arid and semiarid regions, implies a greater demand for food to supply this population as well as the expansion of agricultural lands. Currently, it is estimated that $15 \%$ of the Earth's population (841 million people) live in arid and semiarid regions (Qader et al., 2018). Among the anthropic actions to guarantee food security, water catchment, intended to be used in irrigation systems, deserves attention. Since the beginning of this decade, worldwide groundwater catchment to supply water demand for irrigated fields, has been estimated at approximately at $1000 \mathrm{~km}^{3}$ year $^{-1}$, so that groundwater accounts for $43 \%$ of the water resource in agriculture (Tweed et al., 2018). It is observed that the demand of using irrigation techniques, with inappropriate water management, can cause soil salinization as well the consequent reduction of crops productivity (Hannachi and Labeke, 2018).

The above background shows the need to develop strategies for the efficient use of water resources in the semi-arid, among which is the cultivation of MAC plants as an 
alternative to this region. Forage palm, genus Opuntia and Nopalea, presents this kind of physiological metabolism that is characterized by its expressive tolerance to water deficit and water use efficiency. This specie is grown worldwide mainly to be used as forage, biofuel, medicines, human food, and water treatment (Bayar et al., 2018; Volpe et al., 2018). Forage palm stands out due to its physico-chemical properties both for feeding the herds and for the human diet mostly because it is an important source of minerals, fat, carbohydrates, fibers, energy, fatty acids, high antioxidant capacity. However, it has low protein content (Santiago et al., 2018). For these reasons, scientific community has been investigating this species. Nonetheless, research results on the productivity of irrigated forage palm plants is variable in time and space; thus, there is requirement to summarize these results through meta-analysis.

With meta-analysis technique, it is possible to summarize primary researches on irrigated forage palm and compare them to non-irrigated ones. This technique consists of a systematic literature review and summarization of primary research to obtain the meta-analytical mean estimation of each variable under study. However, the difficulty of obtaining adequate data to carry out meta-analysis has limited its use, particularly because the combined estimates depend on the availability of data, which is not always adequately presented in researches included in the database (Manca et al., 2018).

Based on the above, the objective of this study was to estimate the productivity gain of irrigated and fertilized forage palm plants compared to non-irrigated ones by systematic review and meta-analysis.

\section{Result and Discussion}

\section{Selected references for meta-analysis}

From inclusion of the search strings in each data base (DB), 2,583 references were found, by which 1,204 were from Scholar Google references (DB1), 9 from Scopus (DB2), 8 from Science Direct (DB3), 772 from Spring Link (DB4), 450 from Wiley Online Library (DB5), and 140 from CAPES Thesis and Dissertation Catalog (DB6). The total of references was submitted to initial analysis to verify the relevance to the objective of the study with 2,558 references excluded, 25 references remained, which underwent systematic review. Twenty references were excluded because they did not achieve the inclusion criteria, remaining five references, from which input data were extracted to accomplish the meta-analytical measure estimate (Fig 1).

The results indicate that Scholar Google data base ( $\left.\mathrm{DB}_{1}\right)$ have a higher number of references related to search strings both in English and in Portuguese, probably retrieving references belonged to other databases (Ferraz et al., 2017). These researchers report that for better search efficiency in databases as used in this current research, it is suggested to use English search strings. In historically consolidated databases as $\mathrm{DB}_{2}=$ Scopus, $\mathrm{DB}_{3}=$ Science Direct, $\mathrm{DB}_{4}=$ Springer Link, and $\mathrm{DB}_{5}=$ Wiley Online Library, the indexing process is accurate (Mugnaini and Strehl, 2008), which may be compared with the lower number of references found in these databases in relation to Scholar Google. This is because Google Scholar includes several types of academic material (Noruzi, 2005). It is also important to point out that
Google Scholar does not cover all relevant content and; thus, justifies the search for established bases (Giustini and Barsky, 2005).

The criteria for references insertion into meta-analysis are paramount to guarantee the irrefutable quality so that these criteria should be described in detail (McDonagh et al., 2013). However, well-designed criteria reduce the number of data inputs for meta-analytic estimation (Meline, 2006; Cogo et al., 2017). From 2,583 references, just five of them fulfilled the criteria, assuring the quality of the meta-analysis regarding the relevance of the studies to prove the hypothesis tested.

\section{Subgroups and data normality}

Five subgroups $(S)$ were established which were originated from irrigated and non-irrigated forage palm production data inputs. The first subgroup (S-I) was made up by inputs 28, 29, 30, and 31 from Silva (2017) who studied the increasing levels of ETo replacement $(50,75,100$, and 125\%) plus soil fertilized with $600 \mathrm{~kg} \mathrm{ha}^{-1}$ of nitrogen $(\mathrm{N})$. The second (S-II) was composed by inputs 17, 18, 19, 20, and 21 from Silva (2017) who used irrigation $(25,50,75,100$, and $125 \%$ from ETo) plus fertilization with $150 \mathrm{~kg} \mathrm{ha}^{-1}$ of $\mathrm{N}$. The third (S-III) was made up by inputs $8,9,10,11,12,13,22,23$, 24, 25, and 26 from Sousa (2015). Inputs 89 , and 10 from irrigation levels $(5,10$, and $15 \mathrm{~mm})$ plus soil fertilized with chicken manure, and inputs 11,12 , and 13 from irrigation (5, 10 , and $15 \mathrm{~mm}$ ) plus fertilization with sheep manure, while inputs 22, 23, 24, 25, and 26 were obtained from Silva (2017) who used irrigation (25,50,75, 100, and $125 \%$ from ETo) plus fertilization with $450 \mathrm{~kg} \mathrm{ha}^{-1}$ de N. The forth (S-IV) was made up by inputs $5,6,14,15$, and 16 , which 5 and 6 were obtained from Dantas (2015) who studied 7.5 and $15 \mathrm{~mm}$ irrigation levels, whereas 14, 15, and 16 from Morais (2016), and the fifth (S-V) made up by inputs $1,2,3,4,7$, and 27. Inputs 1, 2, 3, and 4 obtained from Dantas (2015) who studied irrigation levels $8.75,17.50,26.35$, and $35 \mathrm{~mm}$, input 7 from Dantas (2015) under irrigation with $30 \mathrm{~mm}$, and 27 from Silva (2017) under irrigation with $25 \%$ from ETo plus fertilization with $600 \mathrm{~kg} \mathrm{ha}^{-1}$ de N (Fig 2).

Data obtained from different experiments underwent variations due to the edaphoclimatic characteristics of each crop and management systems associated with irrigation. To control this effect of difference among studies, Tupich et al. (2017) created subgroups based on occurrence and severity levels of white-mold on soybean plants. Use of cluster analysis was chosen in the present research (Mishra and DATTA-Gupta, 2018), mainly due to the fact that the sources of variation of each experiment, used in meta-analysis, allows to group similar data within each distinct group (Dash and Mishra, 2018).

Based on Kolmogorov-Smirnov's test, for data normality analysis (K-S), D statistic 0.23 ( $P>0.05$ ) was obtained for all irrigated forage palm plants data inputs (T-E) and $D 0.21$ $(P>0.05)$ for all non-irrigated forage palm plants inputs. However, there is a strong evidence that data from the two forage palm populations follow a normal distribution which comply with assumptions of using meta-analytical estimation. Nevertheless, these data do not follow normal distribution by Shapiro-Wilk's test (S-W) which justify setting-up subgroups of effect moderator. All subgroups data follow a normal distribution by K-S test, while non- 
irrigated palm plants are not normally distributed by the S-W test in the third (S-III) and in the fifth (S-V) subgroups (Table $1)$.

In meta-analysis, data normality is important for assuring the quality of estimation effect. So that, non-normally distributed data could be analyzed by meta-analytical random effects models (Sun et al., 2018). Although current research data are normally distributed by K-S test, Torman et al. (2012) reported that the performance of this test, when compared to other important ones also, is low and those authors endorse S-W test use. When this recommendation was followed, it was verified that nonirrigated palm plants do not have a normal distribution data, which is due to the high heterogeneity in the set of all inputs (T-E) and the low number of combined studies (K) on subgroups (Torman et al., 2012; Bujkiewicz et al., 2015; Snell et al., 2017).

It is important to point out that the assumption of normality is accepted in cases which the sources of variation are different from those under study and they influence the distribution of the data and are known by the researcher. Indeed, Lee and Thomson (2008) studied the flexible parametric meta-analysis models for random effects and they emphasized that it is important to allow distortion, especially when the predictive distribution is of interest, mainly when the suppositions of normality between them do not hold.

\section{Meta-analytical estimation}

From the literature review, it was observed that irrigated forage palm plant experiments were carried out at different locations as well as it was adopted different management systems, which gave heterogeneity to data, suggesting the necessity of using the random effects model. In fact, it was observed high heterogeneity $(P<0.001)$ given by the statistic $\tau^{2}$ (3258.49) that measures the variation among studies and was ratified by the high $\mathrm{I}^{2}(78.10)$ and by the $\mathrm{H}^{2}$ corresponding to 2.14 (Table 2).

At meta-analysis, data normality is important to ensure the estimated effect quality. So, the data that have not normally been distributed may be analyzed by meta-analytic random effects models (Sun et al., 2018). Although the current research data are normally distributed by K-S test, Torman et al. (2012) reported that the performance of this test is low in relation to also established one. These authors recommend $\mathrm{S}-\mathrm{W}$ test use. With this recommendation, we observed that non-irrigated forage palm plants do not have normal distribution, which is due to the high heterogeneity in the set of all inputs (T-E) and the low number of combined studies (K) in the subgroups (Torman et al., 2012; Bujkiewicz et al., 2015; Snell et al., 2017).

The origin of meta-analysis heterogeneity may be clinical, methodological and statistical. Clinical heterogeneity is characteristic to meta-analysis and occurs due to the variability among participants. Methodological heterogeneity refers to the variability among the study designs, samples characteristics, treatments variations, variations in the quality of the project. However, the statistical heterogeneity is due to the variability in the effect measures among different studies and derives from clinical variabilities or from both (Higgins and Green, 2008; Macaskill et al., 2010; Bowden et al., 2011).
On the basis of the above information, it could be seen that meta-analysis heterogeneity, from all inputs (T-E) and subgroups are due to the natural random variability among forage palm plants from original experiments. Moreover, other factors such as variability among the divergent grown conditions of experiments, interaction between both variabilities and the high variability among the different measures between irrigated forage palm plants and nonirrigated forage palm plants from each data input introduced in the meta-analysis can be involved.

From the individual data analysis belonged to each subgroup, the meta-analytic estimation of productivity gain (MD) of the first sub-group (S-I) was $416.85 \mathrm{t} \mathrm{ha}^{-1}$ year-1, with a lower limit (LL) of $261.47 \mathrm{t} \mathrm{ha}^{-1}$ year ${ }^{-1}$, and higher than $572.22 \mathrm{t} \mathrm{ha}^{-1}$ year ${ }^{-1}$. All data inputs $\left(E_{28}, E_{29}, E_{30}\right.$, and $\left.E_{31}\right)$ belonged to this subgroup confirmed a significant $(P<0.01)$ increase in productivity ( $D \pm L>0 t^{\text {ha-1) }}$ (Fig 3 ).

As seen in the first subgroup, the high estimate of productivity was increased due to the irrigation with a gradual rise of the ETo replacement levels on forage palm plants 'Mexican Elephant Ear' plus $600 \mathrm{~kg} \mathrm{ha}^{-1}$ of nitrogen (Silva, 2017). This researcher reported that the productivity will increase because of water reposition. It is linked to the synergistic effect of water availability and high nitrogen content applied through fertigation in the soil.

At the second subgroup, we did not find evidence $(P>0.05)$ that irrigation increase or decrease productivity $(D \pm L=0 t$ $\mathrm{ha}^{-1}$ ), with the meta-analytic mean of $-12.49 \mathrm{t} \mathrm{ha}^{-1}$. This result suggests that in this data grouping forage palm plants productivity can be reduced by $75.90 \mathrm{t} \mathrm{ha}^{-1}$ at the worst scenario, whereas it may increase up to $50.91 \mathrm{t} \mathrm{ha}^{-1}$ at the best scenario (Fig 4 ).

The establishment of the second subgroup was occurred due to the nitrogen amount applied to the soil by Silva (2017) in irrigated forage palm pants. At this subgroup, inputs come from plants fertilized with $150 \mathrm{~kg} \mathrm{ha}^{-1}$ of $\mathrm{N}$. For nitrogen value, they found a significant linear reduction according to the variable levels of ETo replacement: $25,50,75,100$, and $125 \%$. The author reports that the productivity reduction, with this fertilizer management, occurs due to the absence of rainfall, as well as the possible effect of the salts contained in irrigation water.

The low rainfall rates lead to soil salinity problems in arid and semiarid regions, which may limit establishment growth, and survival of forage palm plants. Decreases observed in this research are explained by the scarcity of rainfall and irrigation with saline water due to the reduction in chlorophyll content, quantum efficiency, and PSII photochemical yield, besides the chloroplasts accumulation at the center of the cells and physical damage to cell membranes caused by the effect of salts (Arias-Moreno et al., 2017).

At the third subgroup S-III), there was an average productivity gain of $36.25 \mathrm{t} \mathrm{ha}^{-1}$, varying $95 \%$ at the confidence interval, with a lower limit of $0.23 \mathrm{t} \mathrm{ha}^{-1}$ and upper limit of $72.27 \mathrm{t} \mathrm{ha}^{-1}$. Individually, all data input shows the same productivity between irrigated and non-irrigated palm plants, although each input average indicates an increase (Fig 5).

The productivity gain observed in the third subgroup reflects the effect of irrigation levels associated with the management of fertilization with chicken litter, sheep 
Table 1. Shapiro-Wilk's (S-W) and Kolmogorov-Smirnov's (K-S) normality test for irrigated forage palm plants and non-irrigated forage palm plants. Campina Grande, PB, 2018.

\begin{tabular}{|c|c|c|c|c|c|c|c|c|}
\hline \multirow{3}{*}{ Subgrups } & \multicolumn{4}{|c|}{ Irrigated Forage Palm plants } & \multicolumn{4}{|c|}{ Non- Irrigated Forage Palm plants } \\
\hline & \multicolumn{2}{|c|}{ S-W } & \multicolumn{2}{|c|}{$\mathrm{K}-\mathrm{S}$} & \multicolumn{2}{|c|}{ S-W } & \multicolumn{2}{|r|}{$\mathrm{K}-\mathrm{S}$} \\
\hline & W & $P$ & $\mathrm{D}$ & $P$ & $\mathrm{~W}$ & $P$ & $\mathrm{D}$ & $P$ \\
\hline T-E & 0.84 & $3 E-4$ & 0.23 & 0.07 & 0.89 & $5 E-3$ & 0.21 & 0.11 \\
\hline S-I & 0.99 & 0.97 & 0.15 & 0.99 & 1.00 & 1.00 & 0.50 & 0.19 \\
\hline S-II & 0.98 & 0.96 & 0.14 & 0.99 & 1.00 & 1.00 & 0.50 & 0.11 \\
\hline S-III & 0.95 & 0.63 & 0.16 & 0.89 & 0.72 & $9 \mathrm{E}-4$ & 0.30 & 0.23 \\
\hline S-IV & 0.94 & 0.83 & 0.19 & 0.98 & 0.81 & 0.10 & 0.35 & 0.48 \\
\hline$S-V$ & 0.90 & 0.40 & 0.26 & 0.75 & 0.69 & $4 \mathrm{E}-3$ & 0.38 & 0.27 \\
\hline
\end{tabular}

W: Shapiro-Wilk's statistical test, D: Kolmogorov-Smirnov's statistical test, $P$ : statistical significance probability, T-E: all inputs, S-I: first subgroup, S-II: second subgroup, SIII: third subgroup, S-IV: forth subgroup, and S-V: fifth subgroup.

Table 1. Summary of the heterogeneity tests and the general effects of the meta-analyzes of all data inputs from experiments and subgroup data. Campina Grande, PB, 2018.

\begin{tabular}{|c|c|c|c|c|c|c|c|c|}
\hline \multirow{2}{*}{ Subgroups } & \multicolumn{4}{|c|}{ Heterogenity } & \multicolumn{4}{|c|}{ General Effect } \\
\hline & $\tau^{2}$ & $\mathrm{I}^{2}(\%)$ & $\mathrm{H}^{2}$ & $P$ & $\mathrm{~K}$ & MD & $Z$ & $P$ \\
\hline T-E & 3258.49 & 78.10 & 2.14 & 0.0001 & 31 & 53.54 & 3.93 & 0.0001 \\
\hline S-I & 18157.66 & 73.70 & 1.95 & 0.0098 & 4 & 416.85 & 5.26 & 0.0001 \\
\hline$S-11$ & 0.00 & 0.00 & 1.00 & 0.9900 & 5 & -12.49 & 0.39 & 0.6993 \\
\hline S-III & 0.00 & 0.00 & 1.00 & 0.9900 & 11 & 36.25 & 1.97 & 0.0486 \\
\hline S-IV & 363.38 & 65.20 & 1.70 & 0.0215 & 5 & 13.38 & 1.24 & 0.2143 \\
\hline$S-V$ & 3717.07 & 78.30 & 2.15 & 0.0003 & 6 & 36.89 & 1.31 & 0.1917 \\
\hline
\end{tabular}

$\tau^{2}$. estimation of variability among studies, $I^{2}$ : heterogeneity percentage variance among studies, $H^{2}$. relationship between the size of the confidence interval and the estimate of the measure of effect, $P$ : probability of the significance of the tests, $\mathrm{K}$ : number of combined studies, MD: average of differences, Z: hypothesis test, T-E: all inputs, S-I: first subgroup, S-II: second subgroup, S-III: third subgroup, S-IV: forth subgroup, and S-V: fifth subgroup.

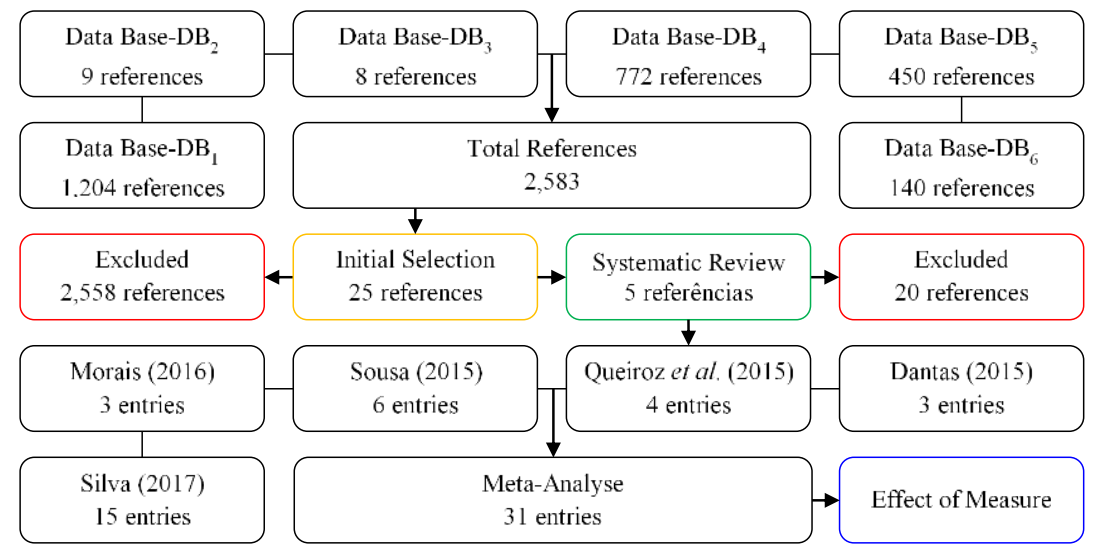

Fig 1. Flow Diagram of Reference Selection Process for systematic review and meta-analysis data collection. Campina Grande, PB. 2017.

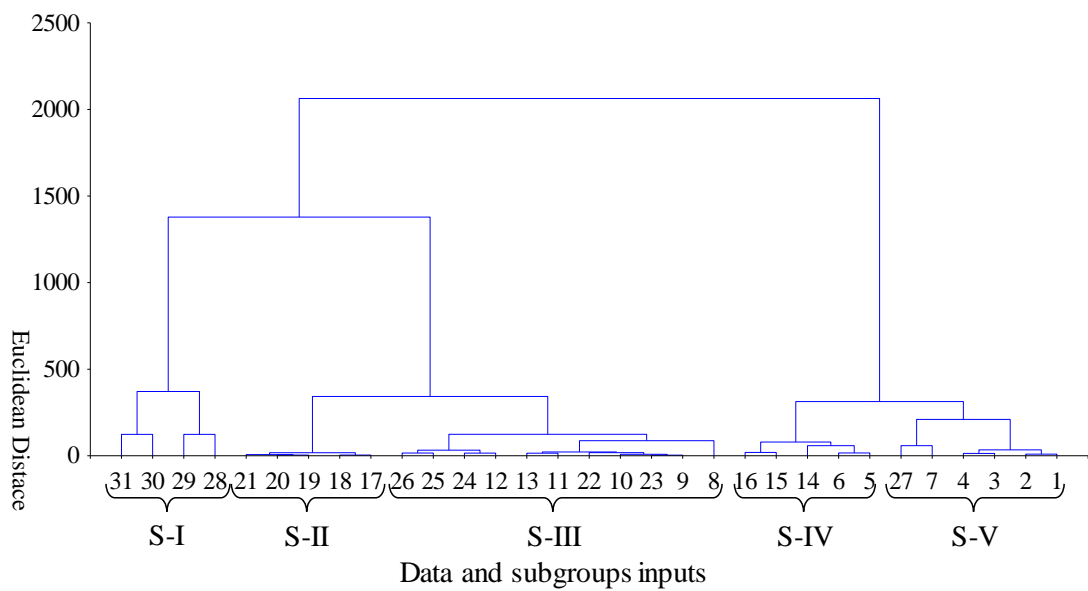

Fig 2. Dendrogram of cluster analysis of data inputs and subgroup establishment with homogeneity within subgroups and heterogeneity among subgroups. Campina Grande, PB, 2017. 


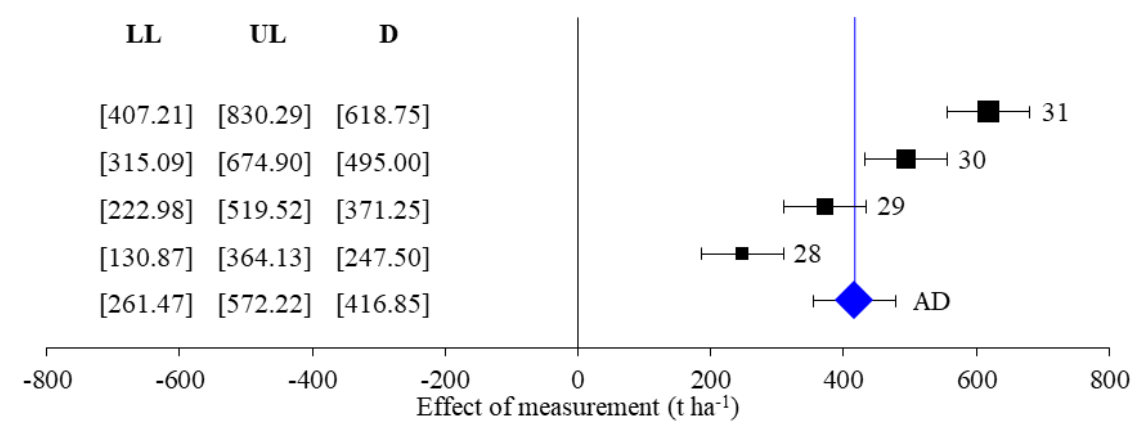

Fig 1. Forest plot of irrigated forage palm plants productivity distribution differences compared to the non-irrigated forage palm plants from the first subgroup. LL: lower limit, UL: higher limit, D: difference of productivity, AD: average of the differences, ( $(\mathbf{)})$ : size of effect and $(\bullet)$ : meta-analytical estimation. Campina Grande, PB, 2017.

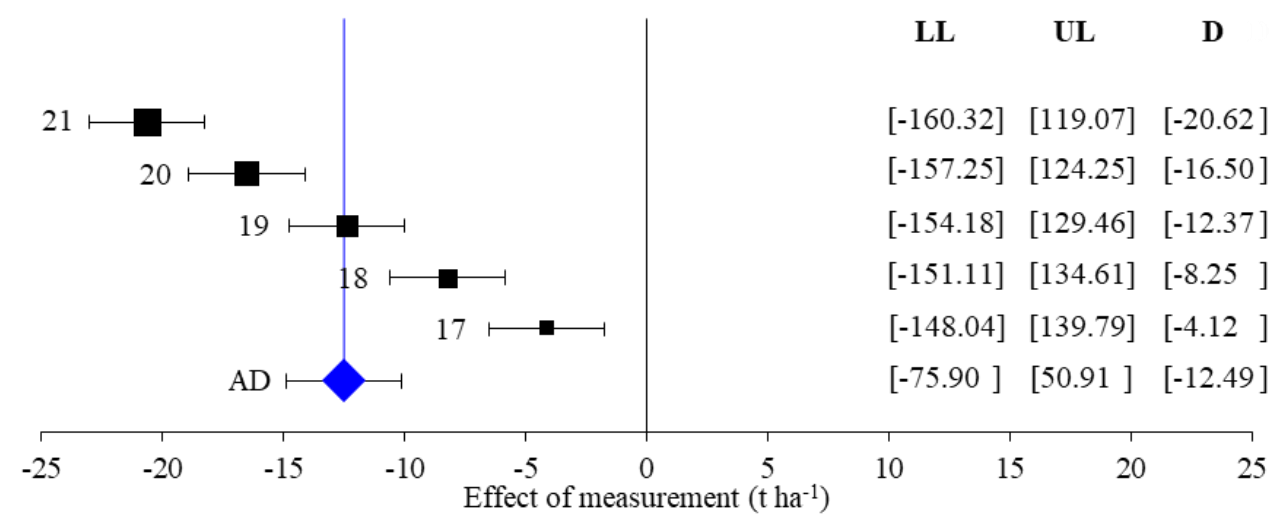

Fig 4. Forest plot of irrigated forage palm plants productivity distribution differences compared to the non-irrigated forage palm plants from the second subgroup. LL: lower limit, UL: higher limit, D: difference of productivity, AD: average of the differences, ( $\mathbf{\square})$ : size of effect and $(\bullet)$ : meta-analytical estimation. Campina Grande, PB, 2017.

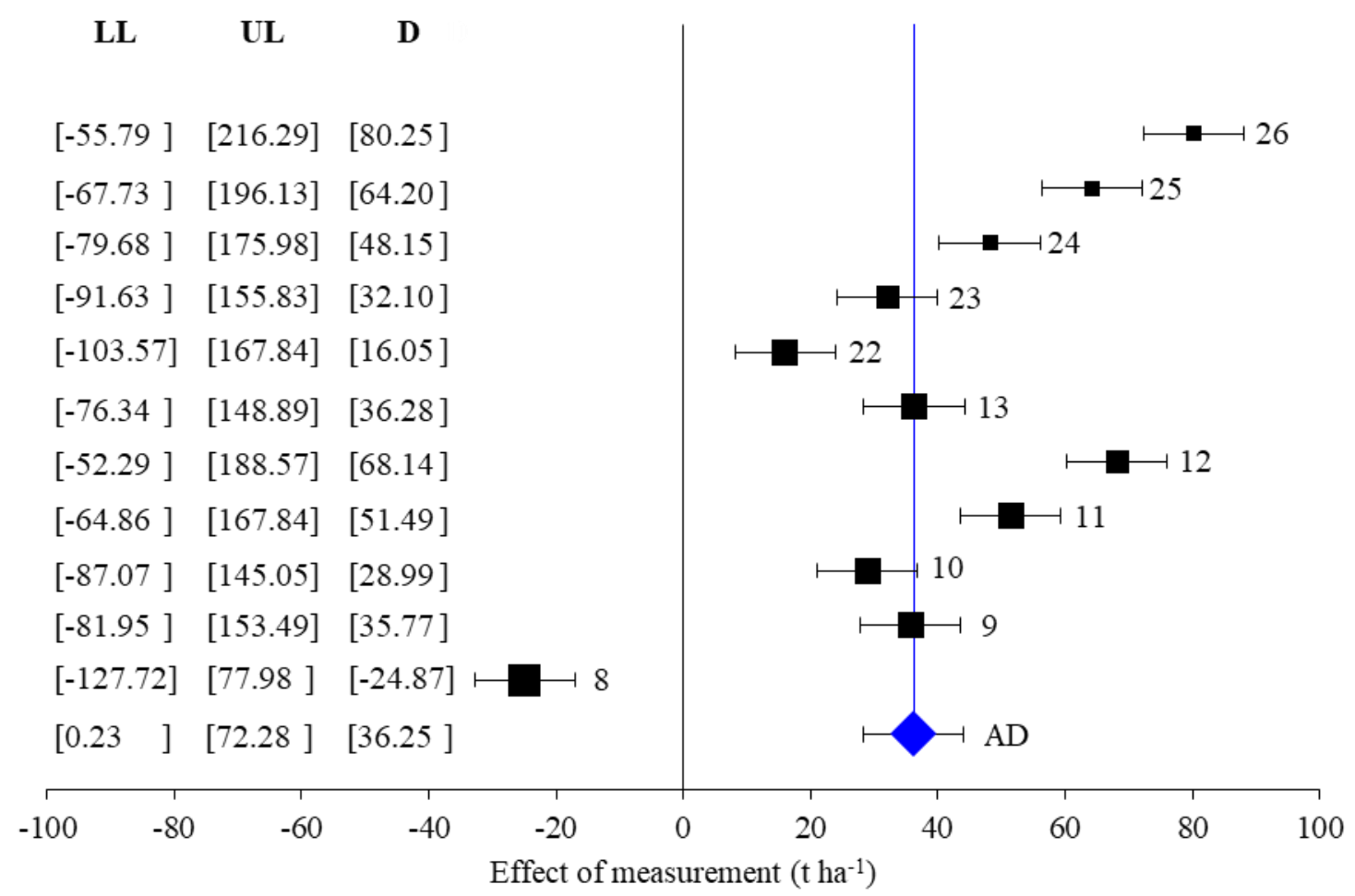

Fig 5. Forest plot of irrigated forage palm plants productivity distribution differences compared to the non-irrigated forage palm plants from the third subgroup. LL: lower limit, UL: higher limit, D: difference of productivity, AD: average of the differences, ( $\mathbf{(})$ : size of effect and ( $\bullet$ : meta-analytical estimation. Campina Grande, PB, 2017. 


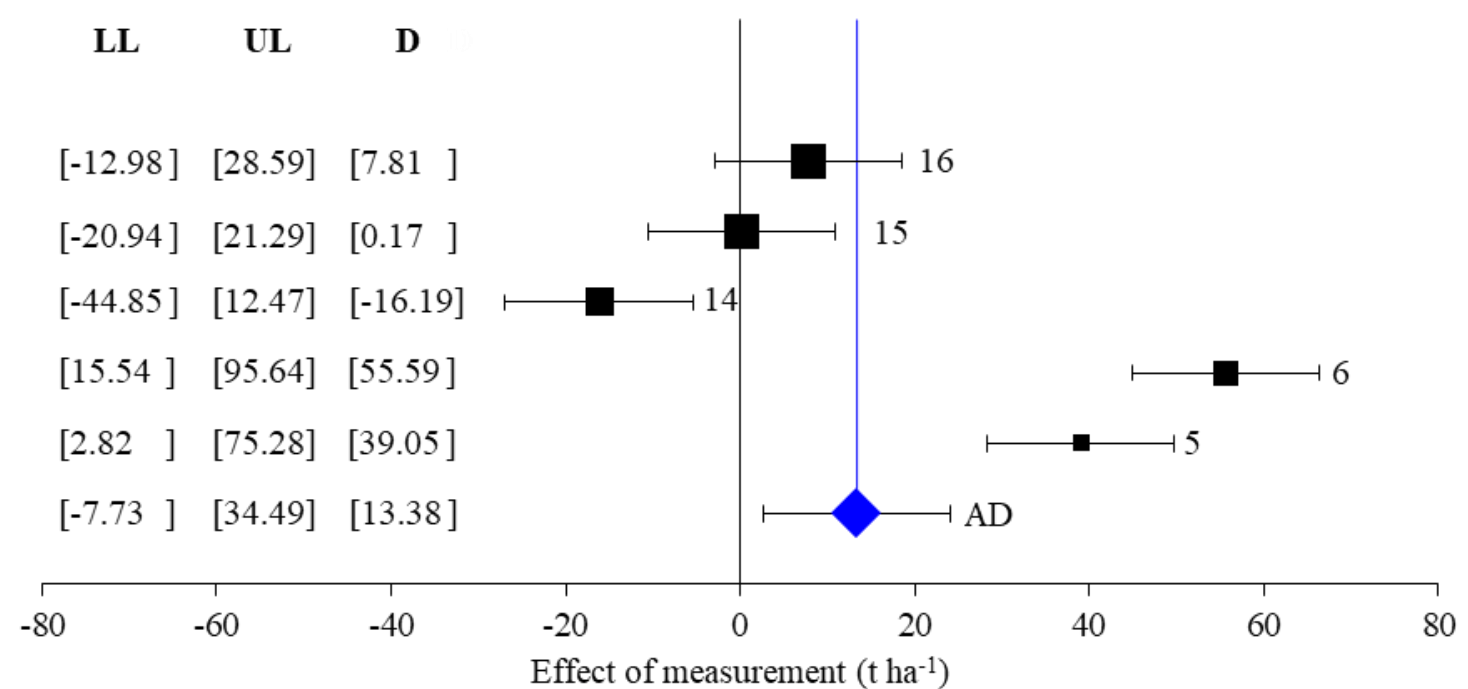

Fig 6. Forest plot of irrigated forage palm plants productivity distribution differences compared to the non-irrigated forage palm plants from the fourth subgroup. LL: lower limit, UL: higher limit, D: difference of productivity, AD: average of the differences, ( $\mathbf{\square})$ : size of effect and $(\bullet)$ : meta-analytical estimation. Campina Grande, PB, 2017.

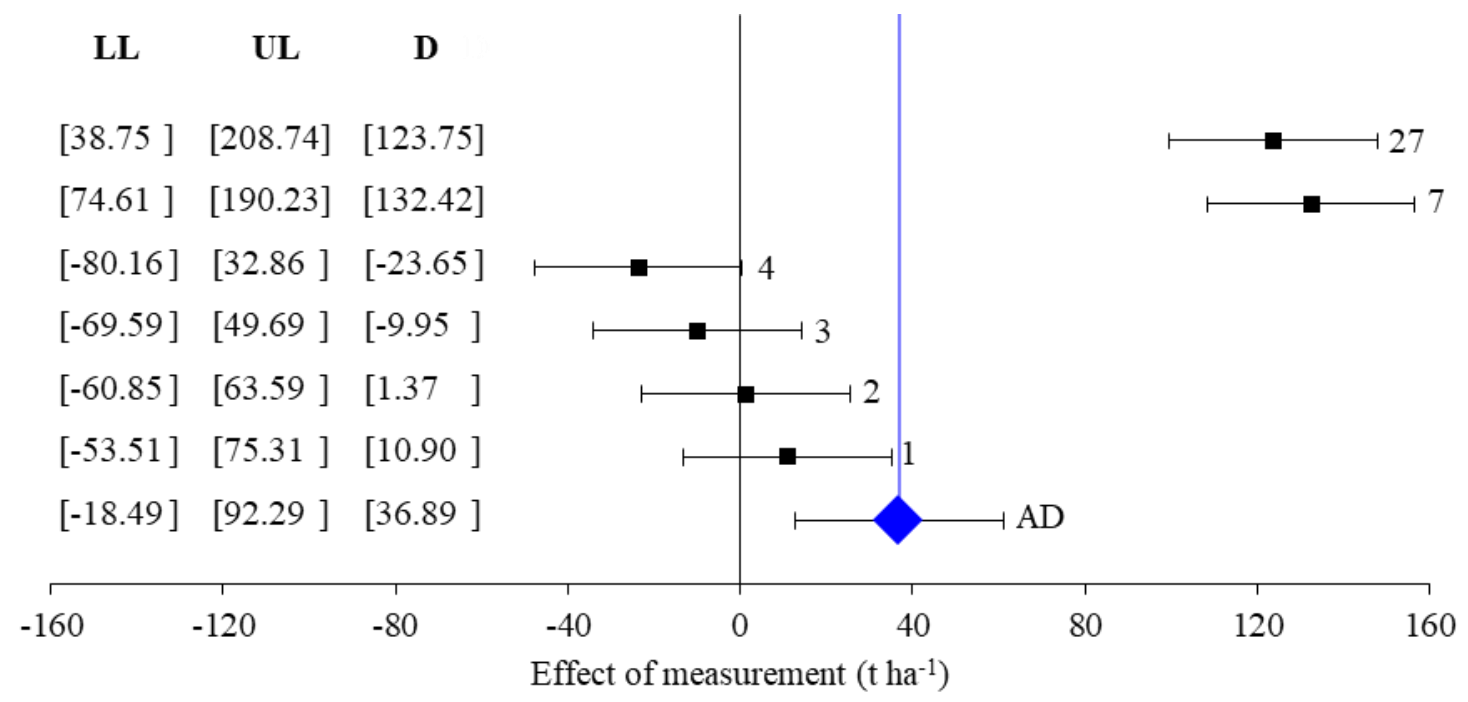

Fig 7. Forest plot of irrigated forage palm plants productivity distribution differences compared to the non-irrigated forage palm plants from the fifth subgroup. LL: lower limit, UL: higher limit, D: difference of productivity, AD: average of the differences, ( $(\mathbf{)})$ : size of effect and $(\bullet)$ : meta-analytical estimation. Campina Grande, PB, 2017.
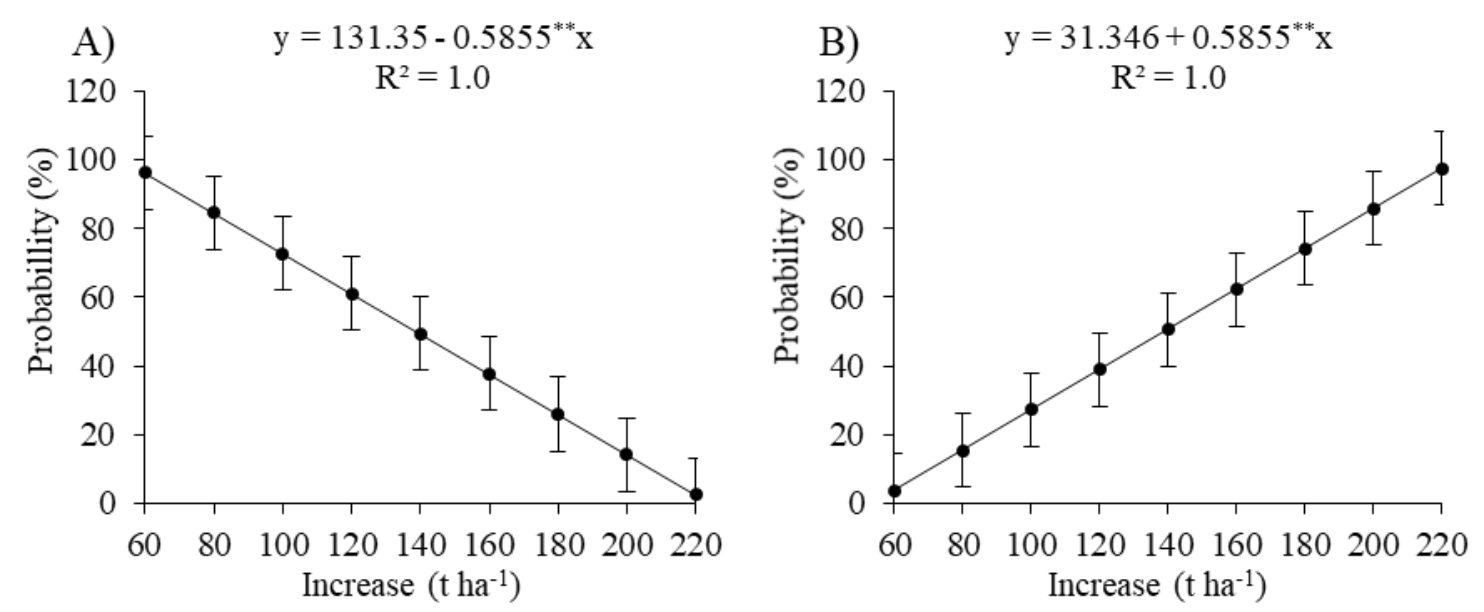

Fig 8. Probability of occurrence (A) and non-occurrence (B) of forage palm plants increasing productivity under irrigation levels. Campina Grande, PB, 2017. 
manure, and mineral nitrogen. However, for 8, 9, 10, 11, 12, and 13 inputs, Sousa (2015) did not find a significant interaction between irrigation and fertilization, which could be related to expressive random data variability and low predictive capacity of the adjustment means models due to irrigation $\left(R^{2}=0.06\right)$ water levels under chicken litter and when irrigated forage palm plants were fertilized with cattle manure $\left(R^{2}=0.02\right)$.

Productivity growth, observed for $22,23,24,25$, and 26 data inputs, confirms the meta-analytic estimate of the productivity gain by irrigation, mainly because Silva (2017) has confirmed the hypothesis that irrigation increases productivity of forage palm plants plus fertilization with 450 $\mathrm{kg} \mathrm{ha}^{-1}$ of $\mathrm{N}$. This author reports that water availability increased cellular turgidity. This information is supported by Barros et al. (2016) who cited that the physiological processes are altered with positive productivity gain. Indeed, semiarid dry condition favors the accumulation of compatible osmolytes to the water deficit tolerance. So that, under irrigation, these high concentration solutes promotes the increase in water intake as well as in the cellular turgor pressure (Taiz et al., 2017).

At the fourth subgroup (S-IV), there was no productivity gain or loss ( $\left.D \pm L=0 \mathrm{tha}^{-1}\right)$, compared to irrigated forage palm plants with non-irrigated ones, although a mean metaanalytic of $13.38 \mathrm{t} \mathrm{ha}^{-1}$ year-1 was obtained, however, there is the possibility of occurring a decrease of $7.73 \mathrm{tha}^{-1}$ at nonirrigated forage palm plants and an increase of $34.49 \mathrm{t} \mathrm{ha}^{-1}$ at irrigated forage palm plants (Fig 6).

There is difference between irrigated forage palm plants and non-irrigated. However, Dantas (2015), extracted 5 and 6 inputs and observed a significant productivity increase in response to irrigation. They also reported that the causes of low yields of forage palm in unfavorable climate regions may be attributed to several factors such as low $\mathrm{CO}_{2}$ uptake, high night transpiration, root death during dry period, and severe wilt of the cladodes, even though the few rainfalls that occurred during the current experiment period have guaranteed the non-irrigated plants survival and productivity.

In this subgroup, the absence of a significant difference between irrigated and non-irrigated forage palm plants productivity is attributed to the environmental facts. Morais (2016) at Pernambuco state semiarid, reported that the warm nights and the low values of air relative humidity induce the loss of water by cladodes and that may make it impossible to use forage palm plants as a fodder reserve during the dry season (Lima et al., 2010). In addition, Dantas et al. (2015) observed that $30 \mathrm{~mm}$ irrigation per month promoted loss of plants caused by soft rot, probably, due to water excess.

At the fifth subgroup (S-V), the meta-analytic measure of $36.69 \mathrm{t} \mathrm{ha}^{-1}$ was achieved, with a lower limit of $-18.49 \mathrm{t} \mathrm{ha}^{-1}$ and higher than $92.29 \mathrm{t} \mathrm{ha}^{-1}$, no difference $(P>0.05)$ was observed between irrigated and non-irrigated forage palm plants, despite significant productivity gains in 7 and 27 data inputs (Fig 7).

No significant difference was observed between irrigated and non-irrigated forage palm plants in the fifth subgroup (inputs 1, 23 , and 4). It may be attributed to meteorological conditions where this research was carried (Queiroz et al., 2015). They reported that the water levels introduced into the system (the sum of rainfall and irrigation) for $0,8.75$, $17.5,26.35$, and $35 \%$ of reference evapotranspiration treatments, corresponded to $976,1048,1096,1152$, and $1202 \mathrm{~mm}$, with $226 \mathrm{~mm}$ difference between the lower and the higher water level applied; thus, water levels did not influence the productivity.

It should be emphasized that excess of water levels may prevent forage palm plant growth and development (FloresHernández et al., 2004; Bajgain et al., 2015), mainly because it is a cactus specie, which requires a low water volume; thus induces greater maintenance of soil moisture (Silva et al., 2014). In fact, productivity gains, in response to the forage palm plants and increasing water levels, are more evident in regions with rainfall levels below from this crop demand, compared to regions which precipitation values are greater than $740 \mathrm{~mm}$ (Queiroz et al., 2015).

\section{Probability of increased production}

For increased productivity levels, we observed that $60 \mathrm{t} \mathrm{ha}^{-1}$ increase took place in irrigated crop compared to nonirrigated one ( $96 \%$ of probability), while for $80,100,120$, $140,160,180,200$, and $220 \mathrm{t} \mathrm{ha}^{-1}$ increment levels, probability was decreased linearly and reached out to 84 , 73, 61, 49, 38, 26, 14, and 3\% (Fig 8A). Probability of no increase in productivity rises linearly, with following values $4,15,27,39,51,62,74,86$, and $97 \%$, respectively.

Tupich et al. (2017) used meta-analytical estimate and the dispersion values of the studies, supposing that the set had a normal distribution. They estimated the probability of gain in productivity using fluazinam fungicide to control soybean white mold. They observed that higher expected productivity lowered the probability of this increment, corroborating with the current study. Paul et al. (2010) studied the influence of treatments with fungicides on wheat and found that, when the response in estimated productivity rises, the probability of occurrence decreases to an equilibrium point, where there is no longer benefit.

It is important to emphasize that to the best of our knowledge there is no previous meta-analytical studies in literature, which compares irrigated with non-irrigated forage palm plants. Therefore, the current study is an important support for decision-making on the use of irrigation to increase productivity of forage palm plants, especially in semi-arid regions, where rainfall does not supply adequately water demand of this specie.

\section{Materials and Methods}

\section{Plant materials}

Opuntia ficus-indica (L.) Mill. is originally from Mexico and Africa. Its advantages lie in the resistance to carmine cochineal and the lower requirement for soil fertility (Cavalcanti et al., 2008; Vasconcelos et al., 2009). The Nopalea cochenillifera (L.) Salm-Dyck has vertical growth, good productivity, is palatable to animals, rich in carbohydrates and low resistance to drought when compared to the giant palm, resistant to carmine cochineal (Silva, 2017).

\section{Search for bibliographic references and systematic review}

The research is classified as quantitative due to the survey and processing of empirical data obtained from primary research (Gerhardt and Silveira, 2009). In relation to its 
nature, this research is applied since it aims to generate knowledge for practical application in relation to the productivity gain of irrigated forage palm plant. In relation to the objectives, this research is classified as explanatory (Gil, 2010). About the procedure, this is a bibliographical research complemented by systematic review and meta-analysis (Littell et al., 2008).

The methodology described by Tupich et al. (2017) was used in this study. A systematic search was carried out between October 23 and 27, 2017, without any restriction of date and location and use of filters. Research was accomplished in the following databases: $\mathrm{DB}_{1}=$ Google Scholar, $\mathrm{DB}_{2}=$ Scopus, $\mathrm{DB}_{3}=$ Science Direct, $\mathrm{DB}_{4}=$ Springer Link, $\mathrm{DB}_{5}=$ Wiley Online Library, and $\mathrm{DB}_{6}=\mathrm{CAPES}$ Thesis and Dissertation Catolog. The following search strings were used: $\mathrm{SS}_{1}=$ "Opuntia" AND "irrigation depth", $\mathrm{SS}_{2}=$ "Opuntia" AND "irrigation depths", $\mathrm{SS}_{3}=$ "Opuntia" AND "irrigation levels", $\mathrm{SS}_{4}=$ "Opuntia" AND "irrigation levels", $\mathrm{SS}_{5}=$ "Nopalea" AND "irrigation depth", $\mathrm{SS}_{6}=$ "Nopalea" AND "irrigation depths", $\mathrm{SS}_{7}=$ "Nopalea" AND "irrigation levels", $\mathrm{SS}_{8}=$ "Nopalea" AND "irrigation levels".

The criteria for inclusion of frequency, hydric regime, ideal irrigation level, and evapotranspiration studies were: (I) Irrigation levels data applied to forage palm plants and their response to production or productivity; (II) Applied water levels data, and (III) experiments that showed measures of variability and data dispersion, as well as the number of repetitions. Bibliographic references flow was carried out as described by Lima et al. (2017) through Mendeley software. Data from selected experiments were submitted to normality analysis by Shapiro-Wilk (Shapiro and Wilk, 1965) and Kolmogorov-Smirnov tests (Kolmogorov, 1933; Smirnov, 1948).

\section{Measures of tendency and dispersion}

The measure of studies effect (D) was obtained from the difference between the productivity from irrigated (PI) forage palm plants and the productivity from non-irrigated (PS), according to the model described by Tupich et al. (2017): $D=(P I-P S)$.

Data variability, inserted into meta-analysis, was estimated by the standard error as describe by Tupich et al. (2017). Therefore, the standard deviation $(\sigma)$ was calculated from coefficient of variation (CV), presented in each study, using irrigated crops average productivity $(\mathrm{PI})$ and non-irrigated crops average yield (PS) through the model: $\sigma=\left((\mathrm{PI}+\mathrm{PS}) / 2^{*} \mathrm{CV}\right) / 100$. For each data input, the number of experiment repetitions ( $n$ ) was obtained to estimate its respective standard error $(\mathrm{S})$, proposed by the model: $\mathrm{S}=\sigma$ / $\mathrm{Vn}$.

\section{Creation and analysis of subgroups}

Data obtained from all studies were submitted to multivariate cluster exploratory analysis (Cluster Analysis) by hierarchical method (Ward's minimum variance) in order to create subgroups so that, the observations of interest, within each subgroup, are homogeneous and the subgroups are different from each other (Mishra and Datta-Gupta, 2018). The analysis was carried out by Statistica v. 7.0 sofware (STATSOFT, 2004).

\section{Meta-analysis}

For the complete data obtained from literature survey and for all sub-groups formed, variability estimation between studies $\left(\tau^{2}\right)$ was assessed by the method described by DerSimonian and Laird (1986). The weighting calculation of each study was carried out by the inverse variance method. Because of high data heterogeneity, we used the random effects model (Santos and Cunha, 2013). Meta-analyses were calculated by software $\mathrm{R}$ with the meta-analytic procedure package "metafor" (Viechtbauer, 2010; R Core Team, 2017).

To use the random effects model from normality test we observed that the set of studies have a normal distribution, with the average effect $(\mu)$ and the variance of the effect $\left(\tau^{2}\right)$ represented by the notation $\theta_{i} \sim N\left(\mu, \tau^{2}\right)$ according to Tupich et al. (2017). Thus, the model has used as effect sources the variation within the study (within-study) among experiments (between-study), as describe below:

$Y j=\mu+\xi j+\varepsilon j$

$Y j$ is the effect observed in the study $j, \mu$ common effect to all studies or the summary measure or meta-analytical measure, $\varepsilon j$ corresponds to the random error of study $\mathrm{j}$, and $\xi j$ is the true effects variation. To obtain the overall estimate and minimize variance, the weighted average was calculated, in which the value assigned to each data entry was given by the inverse of its variance, from the variance within the study and among studies.

The heterogeneity of overall estimates was obtained from $\mathrm{H}^{2}$ and $\mathrm{I}^{2}$ indexes proposed by Higgins and Thompson (2002). With regard to these indexes, Tupich et al. (2017) report that the $I^{2}$ provides the total percentage variance that occurs due to heterogeneity among studies, while $\mathrm{H}^{2}$ makes a relationship between the confidence interval and the estimation of measurement effects. Those researchers emphasize that $\mathrm{H}^{2}$ bigger than 2 suggest that the variation among studies has a substantial influence on the overall effect.

\section{Probability of increased production}

Probability of increased production was established through methodologies described by Paul et al. (2008) and Madden and Paul (2011), with the following model:

$p_{-}(\vartheta)=(\zeta$ new $>\vartheta)=1-\varphi((\vartheta-\zeta) / \sigma)$

Where; $\zeta$ new indicates treatment effect to be estimated, $\vartheta$ it is the answer from estimated productivity, $\sigma$ is the variance square root among studies, $\zeta$ it is the metaanalytical estimate, and $\phi$ is a function of the normal distribution. Probabilities of positive productivity yield were set at levels $60,80,100,120,140,160,180,200$, and $220 t$ $\mathrm{ha}^{-1}$ year $^{-1}$ increase for irrigated forage palm plants. Results were multiplied by 100 and expressed as percentage (Tupich et al., 2017).

\section{Conclusion}

The irrigated forage palm crops have increased the productivity by $53.54 \mathrm{t} \mathrm{ha}^{-1}$, when compared to non-irrigated plots, which could reach $80.25 \mathrm{t} \mathrm{ha}^{-1}$ with highest water levels in the restrictive environment and $26.83 \mathrm{t} \mathrm{ha}^{-1}$ under the lowest water levels in the high rainfall environment. There is the probability of a higher productivity when 
fertilizer is introduced into the system associated with irrigation.

\section{Acknowledgment}

The authors would like to thank the Federal University of Campina Grande (UFCG), Paraíba State University (UEPB), Group of Agricultural Sciences Studies in Semi-Arid (GECAS), National Council for Scientific and Technological Development $(\mathrm{CNPq})$, and the Coordination for the Improvement of Higher Personnel Education (CAPES).

\section{References}

Arias-Moreno DM, Jiménez-Bremont JF, Maruri-López I, Delgado-Sánchez P (2017) Effects of catalase on chloroplast arrangement in Opuntia streptacantha chlorenchyma cells under salt stress. Sci Rep. 7(1):86568670.

Bajgain R, Kawasaki Y, Akamatsu Y, Tanaka Y, Kawamura H, Katsura K, Shiraiwa T (2015) Biomass production and yield of soybean grown under converted paddy fields with excess water during the early growth stage. Field Crops Res. 180:221-227.

Barros JL, Donato SLR, Gomes VM, Donato PER, Silva JÁ, Padilha Júnior MC (2016) Palma forrageira 'gigante' cultivada com adubação orgânica. Reva Agrotec. (1):53656.

Bayar N, Friji M, Kammoun R (2018) Optimization of enzymatic extraction of pectin from Opuntia ficus indica cladodes after mucilage removal. Food Chem. 241(1):127134.

Bowden J, Tierney JF, Copas A, Burdett S (2011) Quantifying, displaying and accounting for heterogeneity in the metaanalysis of RCTs using standard and generalised $Q$ statistics. BMC Med Res Methodol. 11:41.

Bujkiewicz S, Thompson JR, Spata E, Abrams KR (2015) Uncertainty in the Bayesian meta-analysis of normally distributed surrogate endpoints. Stat Methods Med Res. 26(5):2287-2318.

Cavalcanti MCA, Batista AMV, Guim A, Lira MA, Ribeiro VL, Ribeiro Neto AC (2008) Consumo e comportamento ingestivo de caprinos e ovinos alimentados com palma gigante (Opuntia ficus indica Mill) e palma orelha de elefante (Opuntia sp). Acta Sci Anim Sci. 30(2):173-179.

Cogo FD, Guimarães PTG, Rojas EP, Saggin Júnior OJ, Siqueira JO, Carneiro MAC (2017) Arbuscular mycorrhiza in Coffea Arabica L.: Review and meta - analysis. Coffee Sci. 12(3):419-443.

Dantas FDG (2015) Lâminas de água salina e doses de adubação orgânica na produção de palma miúda adensada no semiárido. 92p. Dissertação (Mestrado em Produção Animal) - Universidade Federal do Rio Grande do Norte, Macaíba, RN, 2015.

Dantas FDG, Novaes LP, Lima GFC, Guedes FX, Rego MMT, Souza Sobrinho F, Aguiar EM (2015) Produtividade da palma Miúda sob irrigação com diferentes níveis de água salina e doses de adubação orgânica no semiárido do Rio Grande do Norte. Trabalho apresentado na 52a Reunião Anual da Sociedade Brasileira de Zootecnia, Belo Horizonte, Minas Gerais, 2015.

Dash R, Misra BB (2018) Performance analysis of clustering techniques over microarray data: A case study. Physica $A$. 1:162-176.
Dersimonian R, Laird N (1986) Meta-analysis in clinical trials. Control Clin Trials. 7:177-188.

Ferraz RLS, Costa PS, Dantas Neto J, Anjos FA, Barreto NP, Soares LS, Magalhães ID, Barbosa MA (2017) Opuntia ficusindica (L.) Mill. (Cactaceae) in Climate Change Scenarios and Its Potential for Wastewater Bioremediationin SemiArid Regions: A Systematic Review and Meta-Analysis. Am J Exp Agric. 18(3):1-11.

Flores-Hernández A, Castillo IO, Amador BM, Hernández JLG, Troyo-Dieguez E (2004) Yield and physiological traits of prickly pear cactus 'nopal' (Opuntia spp.) cultivars under drip irrigation. Agric Water Manage. 70(2):97-107.

Gerhardt TE, Silveira DT (2009) Métodos de pesquisa. Editora da UFRGS, Porto Alegre, p 120.

Gil AC (2010) Como elaborar projetos de pesquisa. 5th edn. Atlas, São Paulo, p 200.

Giustini D, Barsky E (2005) A look at Google Scholar, PubMed, and Scirus: comparisons and recommendations. J Canadian Health Libraries Assoc. 26:85-89.

Hannachi S, Labeke MCV (2018) Salt stress affects germination, seedling growth and physiological responses differentially in eggplant cultivars (Solanum melongena L.). Sci Hortic. 228(1):56-65.

Higgins JP, Thompson SG (2002) Quantifying heterogeneity in a meta-analysis. Stat Med. 21(11):1539-1558.

Higgins JPT, Green S (2008) Cochrane handbook for systematic reviews of interventions. Wiley-Blackwell, Chichester, p 672.

Kolmogorov A (1933) Sulla determinazione empirica di una legge di distribuzione. Gior Istitu Italiano Attuari. 4:83-91.

Lee KJ, Thompson SG (2008) Flexible parametric models for random-effects distributions. Stat Med. 27:418-434.

Lima AOL, Mochón LG, Tamayo CB (2017) Identificación de indicadores de resultado en salud en atención primaria. Una revisión de revisiones sistemáticas. Rev Cal Asist. 32(5):278-288

Lima GFC, Silva JGM, Aguiar EM, Teles MM (2010) Reservas forrageiras estratégicas para a pecuária familiar no semiárido: palma, fenos e silagem. Natal: EMPARN, 2010, 53 p. (Circuito de tecnologias adaptadas para a agricultura familiar, 7). Available at: http://adcon.rn.gov.br/ACERVO/EMPARN/DOC/DOC00000 0000024939.PDF [Accessed Nov. 29, 2017].

Lira MA, Santos MVF, Dubeux Júnior JCB, Lira Júnior MA, Mello ACL (2006) Sistemas de produção de forragem: alternativas para sustentabilidade da pecuária. Trabalho apresentado na 43a Reunião Anual da Sociedade Brasileira de Zootecnia, João Pessoa, Paraíba, 2006.

Littell JH, Corcoran J, Pillai V (2008) Systematic reviews and meta-analysis. Oxford Univ Press, 2008.

Macaskill P, Gatsonis C, Deeks JJ, Harbord RM, Takwoingi Y (2010) Analysing and Presenting Results. In: Deeks JJ, Bossuyt PM, Gatsonis C (eds) Cochrane Handbook for Systematic Reviews of Diagnostic Test Accuracy, Version 1.0. The Cochran Collaboration.

Madden LV, Paul PA (2011) Meta-analysis for evidence synthesis in plant pathology: an overview. Phytopathology. 101(1):16-30.

Manca A, Cugusi L, Dvir Z, Deriu F (2018) Non-corresponding authors in the era of meta-analyses. J Clin Epidemiol. 98:159-161.

Mcdonagh $M$, Peterson K, Raina $\mathrm{P}$, Chang S, Shekelle $\mathrm{P}$ (2013) Avoiding Bias in Selecting Studies. In: Mcdonagh M, Peterson K, Raina P, Chang S, Shekelle P (eds) Methods 
Guide for Comparative Effectiveness Reviews. AHRQ, Rockville.

Meline T (2006) Selecting Studies for Systematic Review: Inclusion and Exclusion Criteria. Contemp Issues Commun Sci Disord. 33:21-27.

Mishra S, Datta-Gupta A (2018) Multivariate Data Analysis. In: Mishra S, Datta-Gupta A (eds) Applied Statistical Modeling and Data Analytics. Elsevier, Amsterdã, p 97-118.

Morais JEF (2016) Evapotranspiração real efetiva e indicadores agrometeorológicos e econômicos em cultivo de palma forrageira irrigada. 81p. Dissertação (Mestrado em Produção Vegetal) - Universidade Federal Rural de Pernambuco, Serra Talhada, PE, 2016.

Mugnaini R, Strehl L (2008) Recuperação e impacto da produção científica na Era Google: uma análise comparativa entre o Google Acadêmico e a Web of Science. Rev Eletrônica Bibliotecon Ciênc Inf. 92-105.

Noruzi A (2005) Google Scholar: the new generation of citation indexes. Libri. 55(4):170-180.

Paul PA, Lipps PE, Hershman DE, Mcmullen MP, Draper MA, Madden LV (2008) Efficacy of triazole-based fungicides for fusarium head blight and deoxynivalenol control in wheat: A multivariate meta-analysis. Phytopathology. 98(9):9991011.

Paul PA, Mcmullen MP, Hershman DE, Madden LV (2010) Meta-analysis of the effects of Triazole-Based Fungicides on Wheat Yield and test Weight as Influenced by Fusarium Head Blight Intensity. Phytopathology. 100(2):160-171.

Qader SH, Dash J, Atkinson PM (2018) Forecasting wheat and barley crop production in arid and semi-arid regions using remotely sensed primary productivity and crop phenology: A case study in Iraq. Sci Total Environ. 613(1):250-262.

Queiroz MG, Silva TGF, Zolnier S, Silva SMSE, Lima LR, Alves JO (2015) Características morfofisiológicas e produtividade da palma forrageira em diferentes lâminas de irrigação. Ver Bras Eng Agríc Ambient. 19(10):931-938.

R Core Team (2017) R: A Language and Environment for Statistical Computing. $R$ Foundation for Statistical Computing, Vienna, Austria. Available at: <https://www.Rproject.org>. [Accessed Nov. 29, 2017].

Santiago ED, Domínguez-Fernández M, Cid C, Peña MPD (2018) Impact of cooking process on nutritional composition and antioxidants of cactus cladodes (Opuntia ficus-indica). Food Chem. 240:1055-1062.

Santos EJF, Cunha M (2013) Interpretação crítica dos resultados estatísticos de uma meta-análise: estratégias metodológicas. Millenium. 44:85-98.

Shapiro SS, Wilk MB (1965) An Analysis of Variance Test for Normality (Complete Samples). Biometrika Trust. 52(3/4):591-609.
Silva PF (2017) Crescimento e produtividade de palma forrageira sob diferentes lâminas de irrigação e adubação nitrogenada. 79p. Tese (Doutorado em Engenharia Agrícola) - Universidade Federal de Campina Grande, Campina Grande, PB, 2017.

Silva TGF, Araújo Primo JT, Silva SMS, Moura MSB, Santos DC, Silva MC, Araújo JEM (2014) Indicadores de eficiência do uso da água e de nutrientes de clones de palma forrageira em condições de sequeiro no Semiárido brasileiro. Rev Bragantia. 73(2):184-191.

Smirnov N (1948) Table for estimating the goodness of fit of empirical distributions. Ann Math Stat. 19(2):279-281.

Snell KIE, Ensor J, Debray TPA, Moons KGM, Riley RD (2017) Meta-analysis of prediction model performance across multiple studies: Which scale helps ensure between-study normality for the C-statistic and calibration measures? Stat Methods Med Res. 1-18.

Sousa APF (2015) Palma forrageira adubada e irrigada no Sertão Paraibano. 54p. Dissertação (Mestrado em Zootecnia) - Universidade Federal de Campina Grande, Patos, PB, 2015.

STATSOFT INC (2004) Statistica: data analysis software system. version 7.

Sun J, Freeman BD, Natanson C (2018) Meta-analysis of Clinical Trials. In: Gallin JJ, Ognibene FP, Johnson LL (eds) Principles and Practice of Clinical Research. Elsevier, Amsterdã, p 317-327.

Taiz L, Zeiger E, Moller IM, Murphy A (2017) Fisiologia e desenvolvimento vegetal. 6 th edn. Artmed, Porto Alegre, $p$ 888.

Torman VBL, Coster R, Ribildi J (2012) Normalidade de variáveis: métodos de verificação e comparação de alguns testes não-paramétricos por simulação. Rev HCPA. 32(2):227-234.

Tupich FLB, Fantin LH, Silva AL, Canteri MG (2017) Impacto do controle do mofo-branco com fluazinam na produtividade da soja no Sul do Paraná: metanálise. Summa Phytopathol. 43(2):145-150.

Tweed S, Celle-Jeanton H, Cabot L, Huneau F, Montety VD, Nicolau N, Travi Y, Babic M, Aquilina L, Vergnaud-Ayraud V, Leblanc M (2018) Impact of irrigated agriculture on groundwater resources in a temperate humid region. Sci Total Environ. 613(1):1302-1316.

Vasconcelos AGV, Lira MA, Cavalcanti VLB, Santos MVF, Willadino $L$ (2009) Seleção de clones de palma forrageira resistentes à cochonilha do carmim (Dactylopius sp.). $\mathrm{R}$ Bras Zootec. 38(5):827-831.

Viechtbauer W (2010) Conducting meta-analyses in R with the metafor package. J Stat Software. 36(3):1-48.

Volpe M, Goldfarb JL, Fiori L (2018) Hydrothermal carbonization of Opuntia ficus-indica cladodes: Role of process parameters on hydrochar properties. Bioresource Technol. 247(1):310-318. 